\title{
Formation and Properties of Protoplasts from Antibiotic-producing Strains of Penicillium chrysogenum and Cephalosporium acremonium
}

\author{
By PATRICIA A. FAWCETT, P. BRONWEN LODER, \\ MARGARET J. DUNCAN, T. J. BEESLEY AND E. P. ABRAHAM \\ Sir William Dunn School of Pathology, University of Oxford
}

(Received 29 May 1973)

SUMMARY

Osmotically fragile protoplasts have been prepared by the action of lytic enzymes on the mycelium of Penicillium chrysogenum and Cephalosporium acremonium. The yield of protoplasts, based on DNA content, was up to i $8 \%$. Pretreatment of the mycelium with a thiol compound was necessary with Cephalosporium but not with Penicillium. Electron micrographs indicated that the protoplasts contained all the intracellular organelles of the mycelium and were bounded only by a cytoplasmic membrane. The metabolic activity of the protoplasts, as measured by their respiration, ability to maintain intracellular amino-acid pools, and antibiotic production, was similar to that of control mycelium. L-Valine and L- $\alpha$-aminoadipic acid, which are precursors of penicillin $\mathrm{N}$ and cephalosporin $\mathrm{C}$, were taken up and concentrated by the protoplasts of $C$. acremonium, although the latter transported L-valine less rapidly than did the corresponding mycelium. Protoplasts of $P$. chrysogenum took up L-valine but not L- $\alpha$-aminoadipic acid or its $\delta$-ester. There was little or no transport of the corresponding D-amino acids by protoplasts of either organism.

\section{INTRODUCTION}

One of the difficulties encountered in studies of penicillin and cephalosporin biosynthesis has been associated with the permeability barriers of mycelium. Thus, the interpretation of some experiments has been limited by the failure of a substance added to mycelial suspensions to reach the site of synthesis. For example, no detectable amount of $\left[{ }^{14} \mathrm{C}\right]$ penicillin $\mathrm{N}$ was found to enter the mycelium of Cephalosporium acremonium from the extracellular fluid (Smith, Warren, Newton \& Abraham, 1967). The dipeptide $\delta$-( $\alpha$-aminoadipyl)cysteine was not taken up intact by the mycelium but hydrolysed to its constituent amino acids (Loder, Abraham \& Newton, 1969).

A fragmented hyphal preparation has been obtained by ultrasonic treatment of the mycelium of Cephalosporium acremonium which is able to synthesize a possible biosynthetic intermediate, the tripeptide $\delta$-( $\alpha$-aminoadipyl)cysteinylvaline, from $\delta$-(L- $\alpha$-aminoadipyl)-Lcysteine and DL-[ $\left.{ }^{14} \mathrm{C}\right]$ valine (Loder \& Abraham, I97I). However, no indication of penicillin or cephalosporin formation was obtained in fragmented hyphal systems of this type and it seemed that a study should be made of gentler methods of disrupting the mycelium. The first step of a possible approach was the enzymatic removal of the hyphal walls to form osmotically fragile protoplasts. For example, a bacterium-free extract was prepared from protoplasts of Bacillus licheniformis which was able to synthesize bacitracin from its constituent amino acids in the presence of an energy-generating system (Ishihara, Sasaki \& Shimura, I968), whereas an extract prepared by ultrasonication was less effective (Shimura, 
Sasaki \& Sugawara, I964). This paper describes the preparation of protoplasts from strains of Penicillium chrysogenum and Cephalosporium acremonium and some of the properties of these protoplasts which are relevant to the biosynthesis of penicillins and cephalosporin $\mathrm{C}$.

\section{METHODS}

Cultures and growth conditions. The strain of Cephalosporium acremonium (c91) used in these experiments was isolated at Merck \& Co. Inc., Rahway, New Jersey, U.S.A., and was a mutant of Cephalosporium acremonium I.M.I. 49, I37. The maintenance and growth of the Cephalosporium in shake flasks were as described by Smith et al. (I967).

The strain of Penicillium chrysogenum (C2I) was obtained from Glaxo Research Ltd. Lyophilized cultures were stored in ampoules. They were revived by the addition of I $\mathrm{ml}$ distilled water and transferred to the surface of agar slopes for 7 to 14 days at $27^{\circ} \mathrm{C}$ (Gailey, Stefaniak, Olson \& Johnson, I946). Inoculation medium (5 ml) was added to one slope and the surface growth transferred to one $500 \mathrm{ml}$ shake flask of the same medium $(100 \mathrm{ml})$. The latter was the medium of Tardrew \& Johnson (1958). The flask was placed on a rotary shaker $\left(5 \mathrm{~cm}\right.$ throw) at $160 \mathrm{rev} . / \mathrm{min}$, and $27^{\circ} \mathrm{C}$ for $48 \mathrm{~h}$. Portions $(5 \mathrm{ml})$ of the inoculum were transferred to $100 \mathrm{ml}$ of a medium similar to that of Jarvis \& Johnson (1947) in $500 \mathrm{ml}$ low-baffle shake flasks. The fermentation was carried out on a rotary shaker $\left(5 \mathrm{~cm}\right.$ throw) at $220 \mathrm{rev} . / \mathrm{min}$ and $27^{\circ} \mathrm{C}$ for 24,48 or $72 \mathrm{~h}$.

Materials. DL-[I- $\left.{ }^{14} \mathrm{C}\right]$ Valine $(37.5 \mathrm{mCi} / \mathrm{mmol}), \mathrm{L}-\left[\mathrm{U}-{ }^{14} \mathrm{C}\right]$ valine (Io $\left.\mathrm{mCi} / \mathrm{mmol}\right)$ and $\mathrm{DL}-\alpha-$ amino[ $\left[{ }^{14} \mathrm{C}\right]$ adipic acid $(19.5$ and $25.7 \mathrm{mCi} / \mathrm{mmol})$ were obtained from the Radiochemical Centre, Amersham, Buckinghamshire. $\mathrm{D}-\left[\mathrm{I}-{ }^{14} \mathrm{C}\right]$ Valine $(34 \mathrm{mCi} / \mathrm{mmol})$ was prepared from DL- $\left[\mathrm{I}^{14} \mathrm{C}\right]$ valine as described by Warren, Newton \& Abraham (I967). Dithiothreitol (DTT) was obtained from Calbiochem, Los Angeles, California, U.S.A. DL- $\alpha$-aminoadipic acid $\delta$-ethyl ester was prepared as described by Abraham \& Newton (1954). A dried lytic-enzyme preparation from Cytophaga was a gift from Glaxo Research Ltd. Enzyme preparations from Helix pomatia were the whole (H.P.J.) digestive juice and H.P.J. Special, obtained from L'Industrie Biologique Française, Seine, France. They were freeze-dried after the addition of cysteine hydrochloride ( $0 . \mathrm{I}$ vol. of a I \%, w/v, solution) to inactivate merthiolate preservative (Marini, Arnow \& Lampen, 196I). The yield of freeze-dried material was 0.12 to $0.20 \mathrm{~g} / \mathrm{I} \mathrm{ml} \mathrm{ampoule.} \mathrm{A} \mathrm{lytic-enzyme} \mathrm{preparation} \mathrm{from} \mathrm{Streptomyces} \mathrm{venezuelae} \mathrm{RA}$ García López, Aguirre, Uruburu \& Villanueva, 1967), consisting of a culture filtrate concentrated tenfold, was provided by Dr J. F. Peberdy and Mr R. K. Gibson.

Preparation of protoplasts. Cultures of the Cephalosporium and Penicillium, usually harvested $48 \mathrm{~h}$ after inoculation, were filtered through filter paper (Green's Hyduro No. 904) in a Büchner funnel. The mycelium was washed by three successive resuspensions in the funnel in distilled water. About $5 \mathrm{~g}$ damp-dry mycelium was obtained per $500 \mathrm{ml}$ shake flask.

The Cephalosporium mycelium was resuspended in $0.01 \mathrm{M}$-dithiothreitol (DTT) in

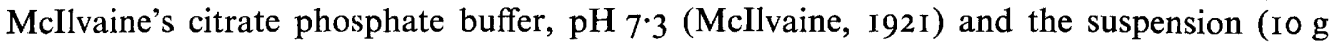
damp-dry mycelium $/ 50 \mathrm{ml}$ ) incubated at $30{ }^{\circ} \mathrm{C}$ for $\mathrm{I} \mathrm{h}$ on a rotary shaker (I $40 \mathrm{rev} . / \mathrm{min}$ ). The mycelium was then filtered and washed with distilled water.

The DTT-treated Cephalosporium mycelium and the untreated Penicillium mycelium

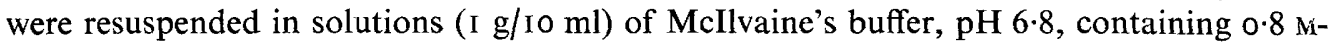
$\mathrm{NaCl}$ plus $0.02 \mathrm{M}^{-} \mathrm{MgSO}_{4}$ and $0.9 \mathrm{M}-\mathrm{NaCl}$ respectively and a lytic-enzyme preparation from Cytophaga $(2 \mathrm{mg} / \mathrm{ml})$, freeze-dried whole or 'special' snail digestive juice (40 and $20 \mathrm{mg} / \mathrm{ml}$ respectively), or concentrated culture filtrate from Streptomyces venezuelae RA $(50 \%, \mathrm{v} / \mathrm{v})$. 
The suspension was dispensed in $5 \mathrm{ml}$ portions into $50 \mathrm{ml}$ Erlenmeyer flasks and incubated at $30{ }^{\circ} \mathrm{C}$, I $20 \mathrm{rev} . / \mathrm{min}$ for 2.5 to $3.5 \mathrm{~h}$.

The resulting mixture of protoplasts and mycelium was centrifuged at $200 \mathrm{~g}$ for $5 \mathrm{~min}$, and the sediment washed twice with the appropriate $\mathrm{NaCl}$ stabilizer. Each pellet was finally resuspended in 20 to $30 \mathrm{ml}$ stabilizer solution and the protoplasts separated from mycelium and debris by filtration under gravity through a no. o and then a no. I porosity sintered-glass funnel. The filtrate and washings with stabilizer were combined and centrifuged at $300 \mathrm{~g}$ for $5 \mathrm{~min}$ to give a protoplast pellet.

Regeneration of mycelium from protoplasts. I. Samples $(0.5 \mathrm{ml})$ of serial dilutions in $0.9 \mathrm{M}-\mathrm{NaCl}$ of a protoplast suspension were spread on the surface of Brain heart infusion agar supplemented with $2 \%(\mathrm{w} / \mathrm{v})$ sucrose and $0.8 \mathrm{M}-\mathrm{NaCl}$. The plates were incubated at $27^{\circ} \mathrm{C}$ for 6 days and the colonies counted. 2. Protoplasts of Penicillium chrysogenum were resuspended $\left(6.6 \times \mathrm{IO}^{7} / \mathrm{ml}\right)$ in shake flasks in $2.5 \mathrm{ml}$ of the ' $\mathrm{QA}(3)$ ' medium of Tardrew \& Johnson (I958) containing $0.8 \mathrm{M}-\mathrm{NaCl}$. The flasks were shaken at $\mathrm{I} 20 \mathrm{rev} . / \mathrm{min}$, at $27{ }^{\circ} \mathrm{C}$, for two days.

Electron microscopy. (i) In one procedure centrifuged pellets of mycelium or protoplasts were covered with osmium tetroxide $(\mathrm{I} \%$, w/v) fixative at pH 6.I (Kellenberger, Ryter \& Sechaud, 1958) for a period of three hours at room temperature, during which time the pellets were divided into small pieces. They were dehydrated in graded ethanol-water mixtures and embedded in Araldite. Sections were stained with lead citrate (Reynolds, 1963). (ii) In a second procedure the method of Gibson \& Peberdy (I972) was used, except that $0.4 \mathrm{M}$-mannitol was replaced by $0.8 \mathrm{M}$-mannitol and Araldite was used for embedding. Procedure (i) was used for the electron micrograph shown in Fig. 3 and procedure (ii) for those shown in Figs. 4 to 6.

Protoplast and mycelial suspensions. For determinations of amino acid uptake and antibiotic production, protoplast pellets from Cephalosporium acremonium and Penicillium chrysogenum were resuspended in a suitable volume $(4$ to $8 \mathrm{ml}$ for protoplasts from $8 \mathrm{~g}$ mycelium) of $0.8 \mathrm{M}-$ and $0.9 \mathrm{M}-\mathrm{NaCl}$ respectively and incubated in $50 \mathrm{ml}$ conical flasks on a rotary shaker (I20 rev./min) at $27{ }^{\circ} \mathrm{C}$.

The behaviour of these suspensions was compared with those of different mycelial suspensions, shaken at $200 \mathrm{rev} . / \mathrm{min}$, which came from batches of mycelium from which the protoplasts had been obtained. Damp-dry mycelium suspended in water ( $\mathrm{I} g / 8 \mathrm{ml})$ directly after harvesting is referred to as fresh mycelium. Mycelium shaken in water $(\mathrm{I} / / \mathrm{lo} \mathrm{ml})$ at I $20 \mathrm{rev} . / \mathrm{min}$ during the time required for the production and harvesting of protoplasts ( 4 to $5 \mathrm{~h}$ ), separated by filtration and resuspended in water $(8 \mathrm{ml})$, is referred to as starved mycelium. Mycelium treated in the manner used for the production of protoplasts except for the omission of lytic enzyme is referred to as control mycelium.

In some experiments additional substances were added to protoplast or mycelial suspensions. These are described in the text.

Uptake of amino acids. DL-[I- $\left.{ }^{14} \mathrm{C}\right]$ Valine, $\mathrm{L}-\left[\mathrm{U}-{ }^{14} \mathrm{C}\right]$ valine, $\mathrm{D}-\left[\mathrm{I}-{ }^{14} \mathrm{C}\right]$ valine or DL- $\alpha$-amino$\left[{ }^{-1}{ }^{14} \mathrm{C}\right]$ adipic acid (each $5 \mu \mathrm{Ci}$ ) were added separately to shaken suspensions of protoplasts or of mycelium. Samples $(0.5 \mathrm{ml})$ were removed at intervals, centrifuged or filtered immediately, and the resulting pellets washed three times at the centrifuge with fresh suspension fluid. The protoplast pellet was lysed with distilled water ( $\mathrm{I} \mathrm{ml}$ ), the lysate centrifuged at $\mathrm{I} 5000 \mathrm{~g}$ for $\mathrm{Io}$ min and the supernatant removed. The mycelial pellet was shaken for $5 \mathrm{~min}$ with $\mathrm{I} \mathrm{ml}$ of ice-cold $70 \%(\mathrm{v} / \mathrm{v})$ ethanol, then for I min with I $\mathrm{ml}$ of ice-cold water, and the ethanol and water extracts combined.

After removal of samples for counting, the mycelial extract and protoplast lysate were 
freeze-dried. Amino acids were extracted from the residues with $70 \%(\mathrm{v} / \mathrm{v})$ ethanol $(2 \times 200 \mu \mathrm{l})$ and the ethanol extracts were diluted with water and freeze-dried. The resulting products were analysed on paper by two-dimensional electrophoresis at $\mathrm{pH} 4.5$ and chromatography in butan-I-ol-acetic acid-water ( $4: 1: 5$ by vol.) followed by coloration with ninhydrin. Semi-quantitative estimates of the amounts of amino acids present were made visually. Quantitative analyses were carried out with a Biocal BC 100 Minichrom amino acid analyser with a high sensitivity linear-output colorimeter by the standard I column programme for protein hydrolysates (Spackman, Stein \& Moore, 1958).

General methods. Antibacterial assays of penicillin $\mathrm{N}$ and cephalosporin $\mathrm{C}$ were carried out as described by Smith et al. (1967). The method of assay of benzylpenicillin was similar, except that Staphylococcus aureus (NCTC 657I) was used as the test organism. Paper chromatography and electrophoresis, autoradiography and the counting of radioactive compounds on paper were also carried out as described by Smith et al. (1967). The radioactivities of samples $(25 \mu \mathrm{l})$ of solutions were determined in a Nuclear Chicago Unilux IIA scintillation counter after addition of each sample to $3.0 \mathrm{ml}$ of the water-miscible scintillation mixture of Bruno \& Christian (196I). DNA was determined by the method of Burton (I968) and protein by the method of Lowry, Rosebrough, Farr \& Randall (I95I). Rates of respiration of protoplasts and mycelium were determined in Warburg flasks with $2 \mathrm{M}-\mathrm{KOH}$ in the centre well and air as the gas phase.

The protoplasts were examined under a phase-contrast microscope, and their diameters measured with a calibrated ocular micrometer. They were counted in a Neubauer counting chamber.

Protoplasts were stained with a solution of acridine orange in distilled water. In order to obtain correctly stained preparations it was often necessary to alter the concentration of the stain or the time of staining. A concentration of $0 . \mathrm{I} \%(\mathrm{w} / \mathrm{v})$ for $5 \mathrm{~min}$ was usually satisfactory. The preparations were examined with transmitted fluorescence light. The light source was a HBO 200 mercury-vapour lamp. The nucleus appeared green, due to DNA fluorescence, while the cytoplasm fluoresced orange due to RNA.

\section{RESULTS}

\section{Formation of protoplasts and reversion to mycelium}

The age of the culture used is an important factor in the conversion of both Cephalosporium acremonium and Penicillium chrysogenum to protoplasts. The highest yields were obtained with mycelium from $48 \mathrm{~h}$ cultures. With both organisms the use of mycelium harvested after $72 \mathrm{~h}$ resulted in yields which were considerably lower. No protoplasts were produced by a $24 \mathrm{~h}$ culture of the Penicillium and relatively few by the Cephalosporium sp.

Recoveries of protoplasts were up to $18 \%$ with Cephalosporium acremonium and up to $12 \%$ with Penicillium chrysogenum when based on the DNA content of protoplasts and mycelium. With Cephalosporium recoveries were also estimated on the basis of protein content and were I to $3 \%$. However, the numbers of protoplasts recovered (usually about $10^{8} / \mathrm{g}$ damp-dry mycelium) were somewhat lower than those produced, since a few were trapped in the mycelial mat during filtration. More vigorous washing of the mat resulted in contamination of the protoplasts with small fragments of mycelium.

Without pretreatment with a thiol compound the walls of the Cephalosporium were not readily digested by the preparations of lytic enzyme from either Helix pomatia or Cytophaga. Pretreatment of the mycelium with either $0.02 \mathrm{M}-2$-mercaptoethanol or $0.01 \mathrm{M}$-dithio- 
threitol for $\mathrm{I} h$, followed by incubation with the lytic-enzyme preparations, resulted in the formation of osmotically fragile protoplasts.

After incubation for $\mathrm{I} h$ in Helix pomatia enzyme, mycelium which had been pretreated with dithiothreitol had produced more protoplasts than similar mycelium pretreated with 2-mercaptoethanol, but after $3 \mathrm{~h}$ incubation the yield of protoplasts from the two samples did not differ significantly. However, the Cytophaga enzyme released 50 to $100 \%$ more protoplasts after I or $3 \mathrm{~h}$ from DTT-treated mycelium than did Helix pomatia enzyme.

In contrast to the situation with the Cephalosporium, pretreatment of Penicillium chrysogenum with DTT did not facilitate protoplast formation. The lytic-enzyme preparations from Helix pomatia (HPJ) and Streptomyces venezuelae RA were about equally effective in the production of protoplasts. But the preparation from Cytophaga was less effective than HPJ and the Helix pomatia special preparation was more effective than the latter.

The nature of the osmotic stabilizer and also its concentration had an effect on protoplast formation. Sodium chloride, potassium chloride and ammonium chloride at concentrations of 0.6 to $0.9 \mathrm{M}$ were the most effective of the stabilizers tested. Very few protoplasts were produced from Penicillium chrysogenum in sorbitol, mannitol, or sucrose, and relatively low yields were obtained in these stabilizers from Cephalosporium acremonium. More protoplasts were obtained from $C$. acremonium in $\mathrm{NH}_{4} \mathrm{Cl}\left(10.6 \times 10^{8} / \mathrm{ml}\right)$ than in $\mathrm{NaCl}\left(6.4 \times 10^{8} / \mathrm{ml}\right)$ from a similar amount of the same batch of mycelium. However, the DNA content of the former suspension was $3.2 \mu \mathrm{g} / \mathrm{ml}$ and that of the latter $5.7 \mu \mathrm{g} / \mathrm{ml}$.

When protoplasts of Cephalosporium acremonium amd Penicillium chrysogenum were spread on nutrient agar containing $\mathrm{NaCl}$ as an osmotic stabilizer, 0.5 to I $\%$ of the protoplasts yielded visible colonies after 3 days. In liquid medium the first stage of regeneration with protoplasts of $P$. chrysogenum was observed after $2 \mathrm{~h}$, when a small protuberance was noticed on some of them. After $18 \mathrm{~h}$ several stages of regeneration were observed. One, or sometimes.two, hyphal tubes had emerged from some protoplasts, while others appeared to have produced short chains of cells from which a hyphal tube emerged at one end. In addition, a considerable amount of mycelium was present together with some intact protoplasts.

\section{Morphological observations}

Phase-contrast and fluorescence microscopy. With both fungi, protoplasts were formed mainly by swelling in localized areas of the mycelium, but occasionally their formation began with a bud-like emergence towards the tip of the growing mycelium. The appearance of protoplasts during treatment of Penicillium chrysogenum with the HPJ enzyme is shown in Fig. I and harvested protoplasts from both fungi are shown in Fig. 2.

The protoplasts from both fungi were spherical and contained one or more large vacuoles. Staining with acridine orange indicated that one nucleus was present in the majority of protoplasts. However, two or more nuclei were also observed and the latter situation was more common with the protoplasts from Penicillium chrysogenum. Two preparations of protoplasts of $P$. chrysogenum contained I I 6 and I $8.9 \mu \mathrm{g}$ DNA $/ 10^{8}$ protoplasts respectively. A preparation from Cephalosporium acremonium contained $8.8 \mu \mathrm{g} \mathrm{DNA} / 10^{8}$ protoplasts.

The size of the protoplasts depended on the concentration of the stabilizer used and also on the time of incubation with the lytic enzyme. After $2 \mathrm{~h}$ incubation the average diameter of protoplasts from Penicillium chrysogenum in $\mathrm{I} \cdot \mathrm{O} \mathrm{M}-\mathrm{NaCl}$ was $5.4 \mu \mathrm{m}$ and in $0.4 \mathrm{M}-\mathrm{NaCl}$ it was $7.4 \mu \mathrm{m}$. The corresponding diameters after $4 \mathrm{~h}$ incubation were 6.8 and $8.6 \mu \mathrm{m}$. Overall, protoplasts with sizes ranging from 2.7 to $10.7 \mu \mathrm{m}$ were seen under these conditions. The average diameter of the protoplasts from Cephalosporium acremonium after $4 \mathrm{~h}$ was $4.7 \mu \mathrm{m}$ 


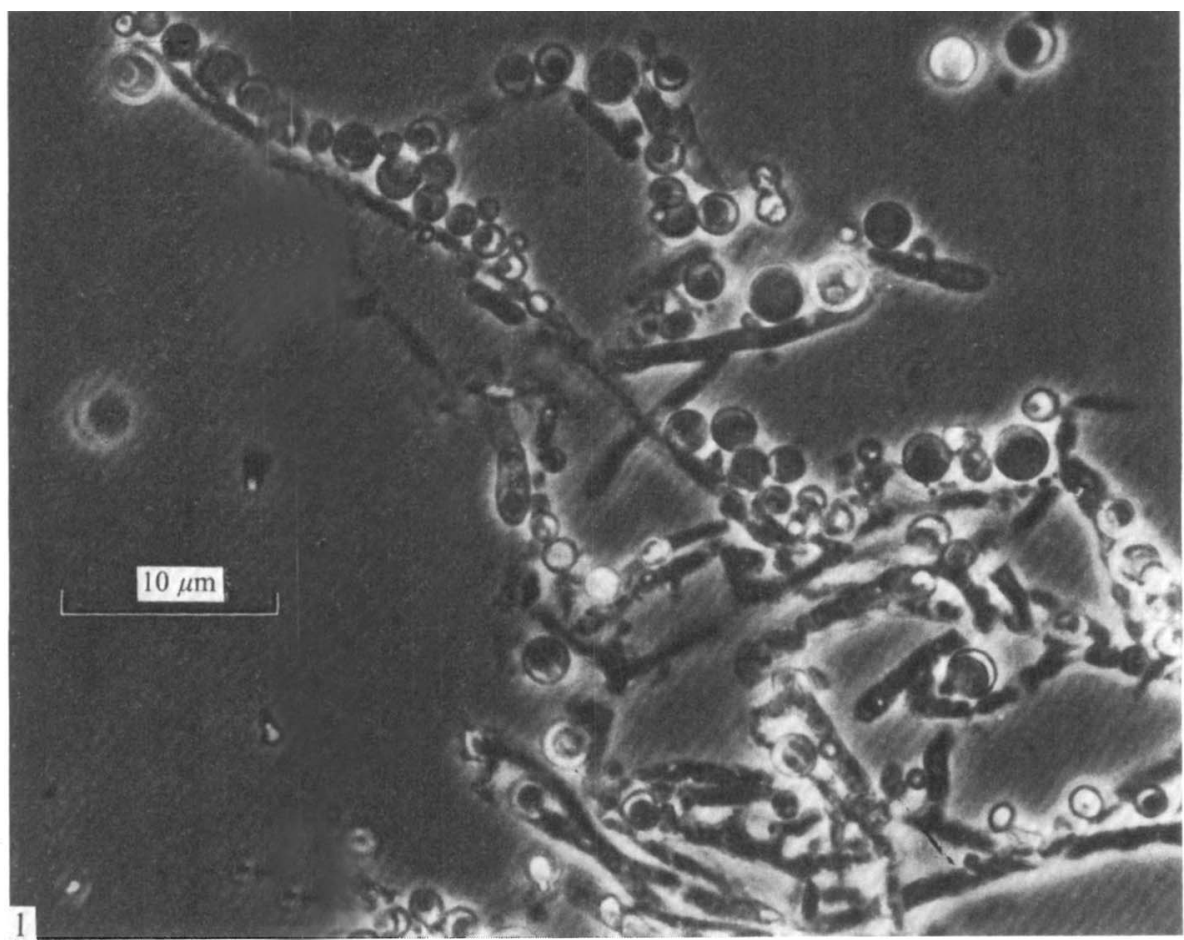

Fig. I. Formation of protoplasts from Penicillium chrysogenum after $5 \mathrm{~h}$ incubation in lytic enzyme from Helix pomatia and in the presence of $0.9 \mathrm{M}-\mathrm{NaCl}$.
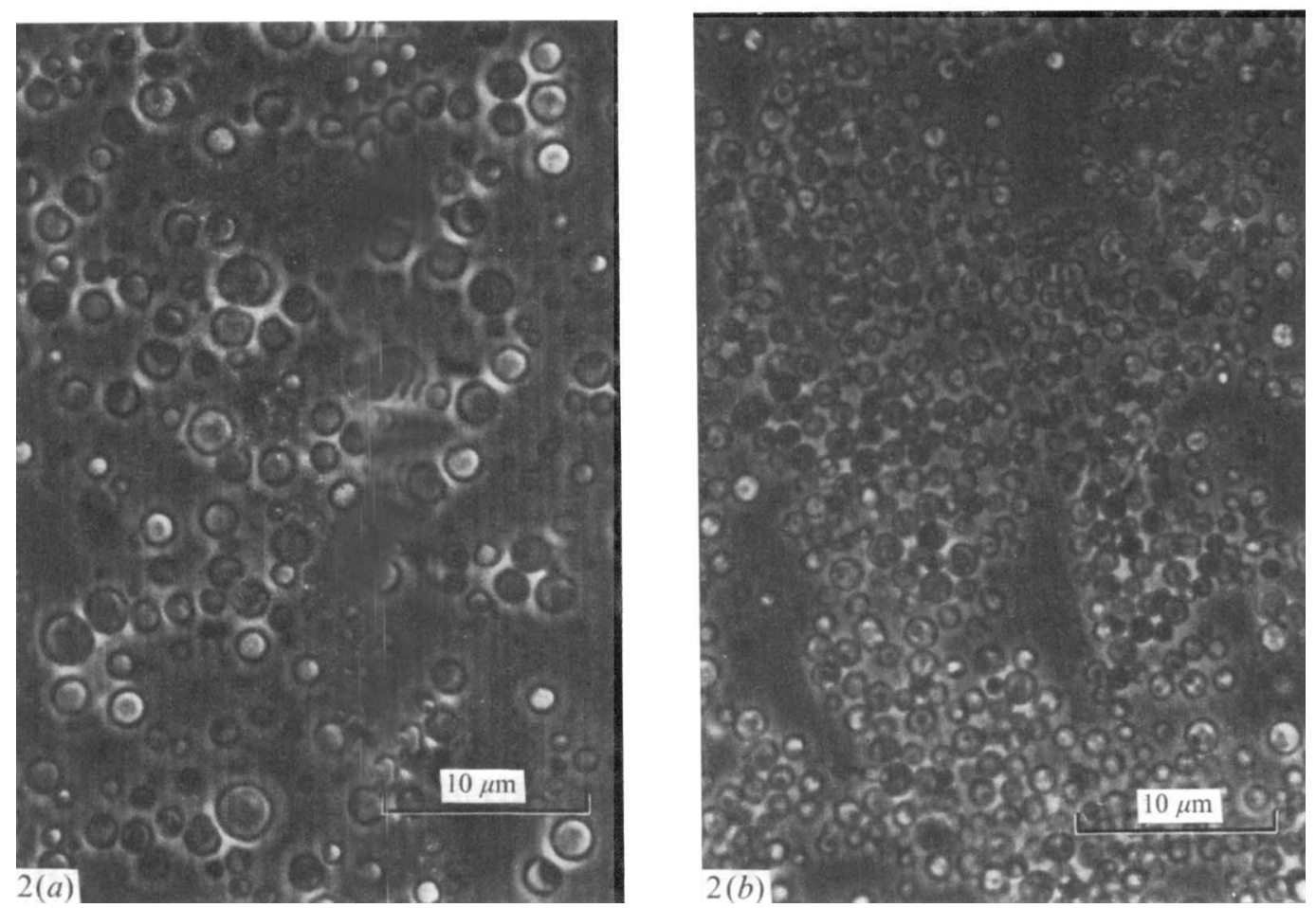

Fig. 2. Suspensions of harvested protoplasts from (a) Penicillium chrysogenum; (b) Cephalosporium acremonium in $0.9 \mathrm{M}-\mathrm{NaCl}$. 


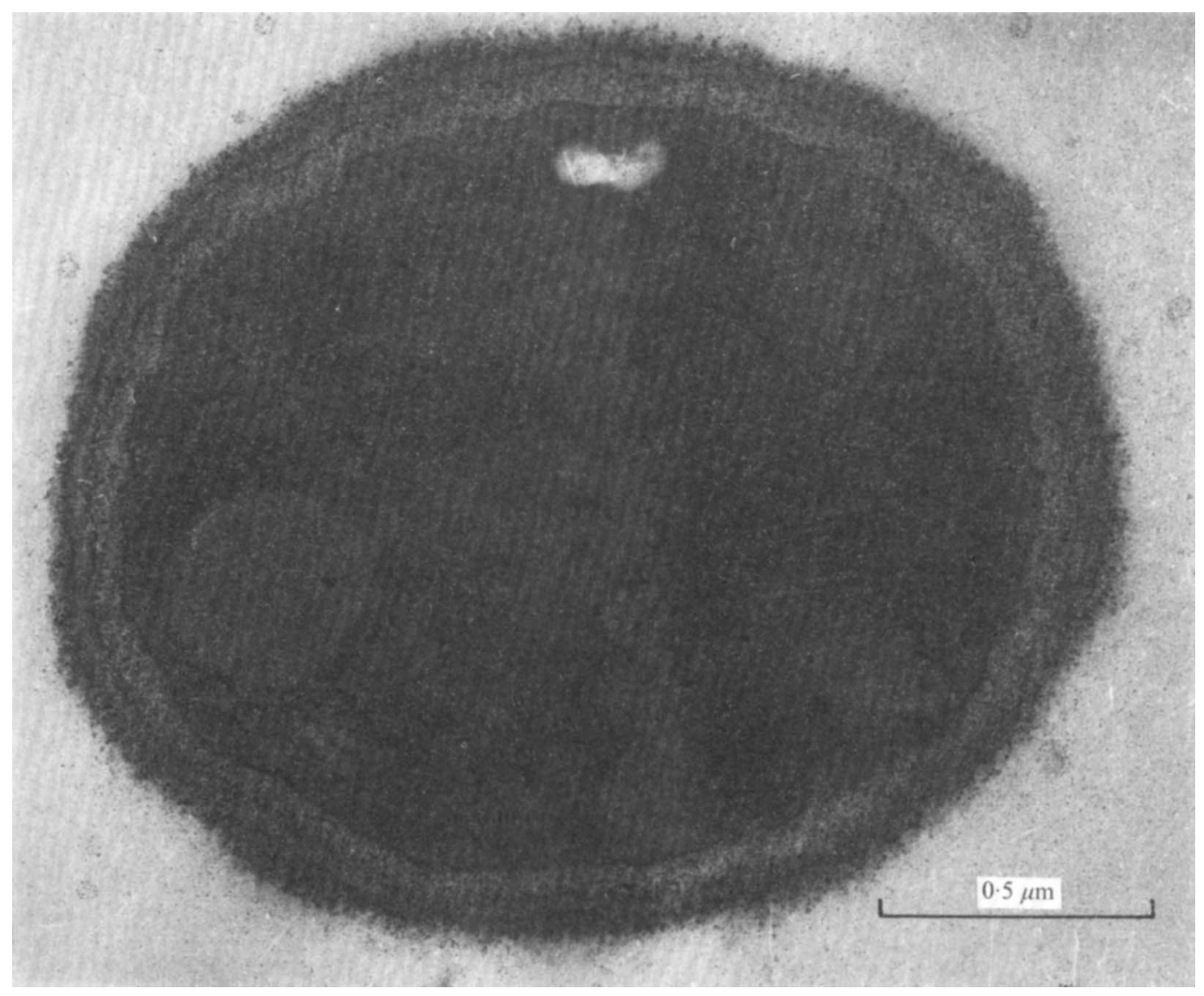

Fig. 3. Cross-section of a hyphal strand of Cephalosporium acremonium showing layered wall structure.

in $0.4 \mathrm{M}-\mathrm{NaCl}$ and $3.4 \mu \mathrm{m}$ in $\mathrm{I} \cdot 0 \mathrm{M}-\mathrm{NaCl}$, and under these two conditions protoplasts were seen with diameters ranging from $\mathrm{I}$ to $7 \mu \mathrm{m}$.

When the concentration of $\mathrm{NaCl}$ in the suspension fluid of protoplasts from Penicillium chrysogenum was gradually reduced to below $0.4 \mathrm{M}$, or of protoplasts from Cephalosporium acremonium to below $0.6 \mathrm{M}$, some lysis occurred and free vacuoles were released. On further dilution of the stabilizer, the remaining protoplasts lysed and the vacuolar membrane burst also.

Electron microscopy. Electron micrographs of the untreated mycelium of Cephalosporium acremonium and Penicillium chrysogenum show that the hyphae were bounded by a wall about I $70 \mathrm{~nm}$ thick, and that the wall appeared to be composed of five different layers, two of which were thin and electron-dense. The external layer was diffuse, and the inner layer close to the cytoplasmic membrane as shown in Fig. 3. The cytoplasm showed areas which were apparently filled with tightly packed ribosomes, but there were other amorphous areas which were devoid of them. Some hyphal sections had one or more vacuoles and other bodies which were electron-dense and may have contained lipid. With C. acremonium, at least, there were tubular invaginations in some hyphae at the cytoplasmic membrane.

After pretreatment of Cephalosporium acremonium with $0.01 \mathrm{M}$-dithiothreitol there was 


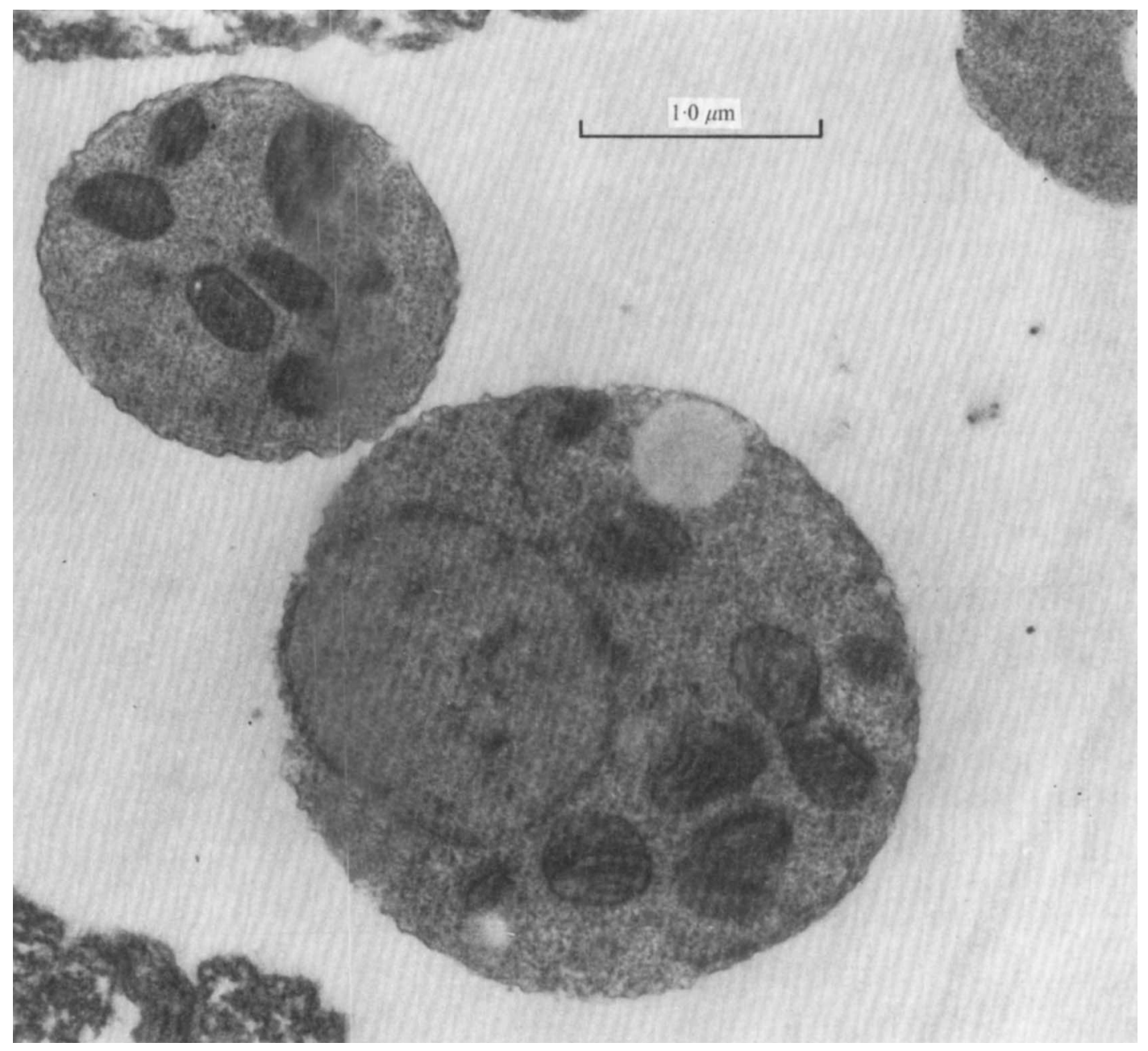

Fig. 4. Sections of protoplasts from Cephalosporium acremonium, showing ribosomes, mitochondria, nucleus and small vacuole.

no apparent decrease in the thickness of the hyphal wall but, in some cases, the inner layer of the wall no longer seemed to be in intimate contact with the cytoplasmic membrane. Dithiothreitol did not have any discernible effect on the internal organisation of the hyphae.

The protoplasts of both organisms appeared to be bounded only by the cytoplasmic membrane (Fig. 4 to 6). In some cases protuberances of the plasmalemma were observed. Points of contact between the double-layered cytoplasmic membranes of two protoplasts from Penicillium chrysogenum can be seen in Fig. 6 and confirm the virtual absence of wall material.

Apparently the protoplasts contained all the intracellular organelles of the normal hypha. The internal structure could be discerned more easily than that of the mycelium, because of the diffuseness of the cytoplasm in which the ribosomes were no longer so tightly packed. Each protoplast contained several mitochondria, which were round or ovoid in the Cephalosporium acremonium protoplasts but often appeared dumbell shaped in Penicillium chrysogenum. Long filiform cristae could be seen in each mitochondrion. 


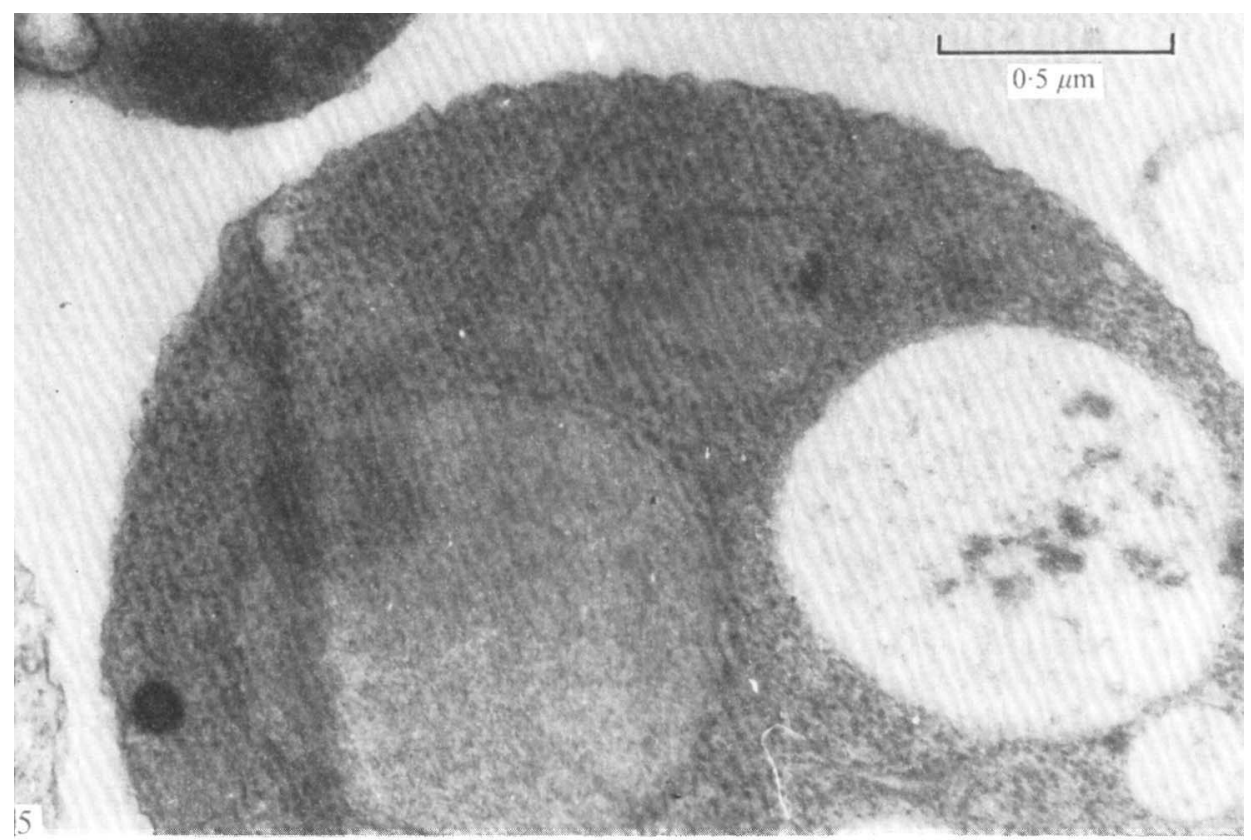

Fig. 5. Section of part of a protoplast from Cephalosporium acremonium, showing nucleus with densely stained region, probably a nucleolus.

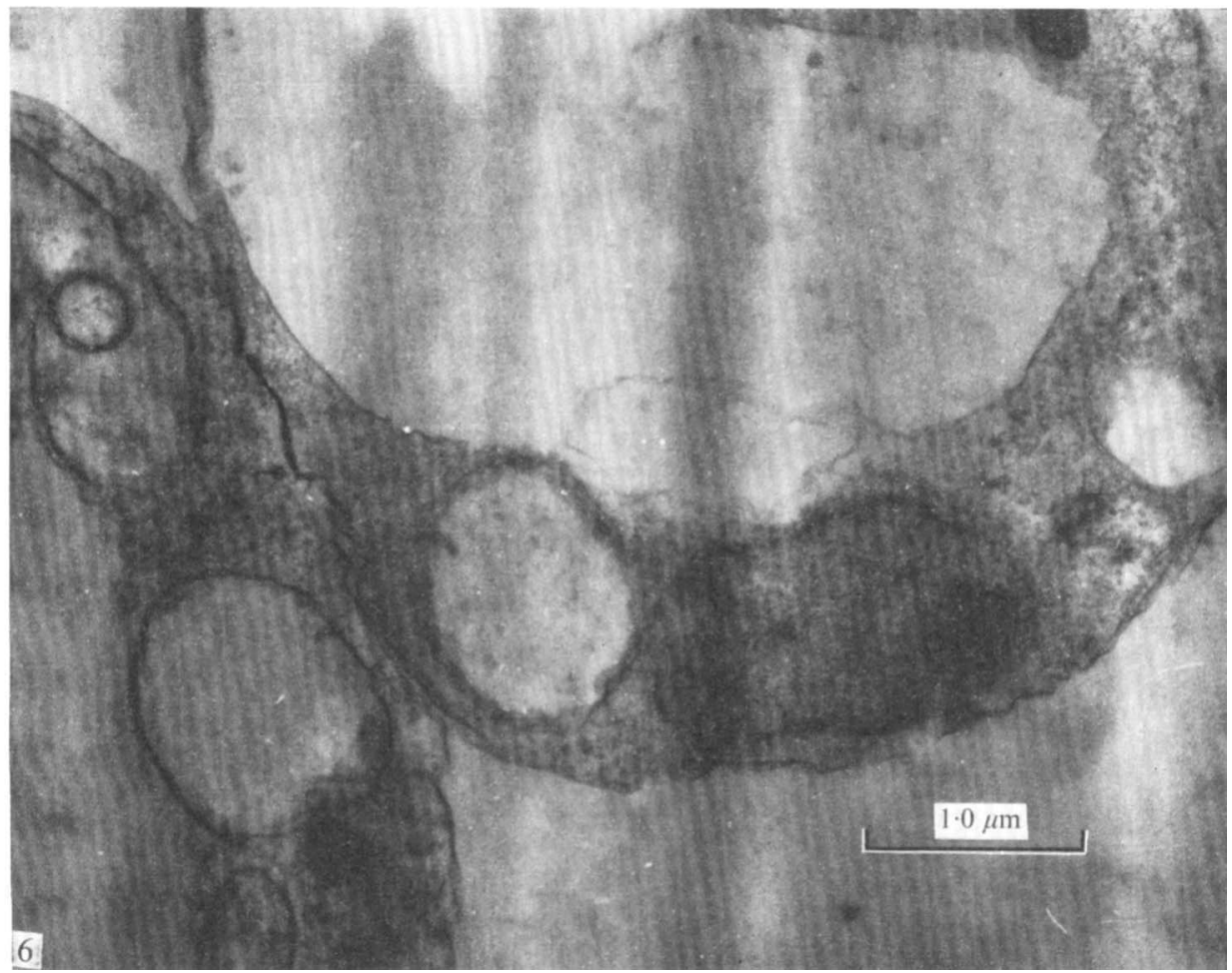

Fig. 6. A section of two protoplasts from Penicillium chrysogenum, showing a large vacuole and points of contact between the two cytoplasmic membranes. 


\section{Table I. Amino acid pool of protoplasts and mycelium}

The values for mycelia represent total $\mu$ moles of amino acids/g of damp-dry mycelium, determined by quantitative amino acid analysis. The values for protoplasts $\left(\mathrm{I} \cdot 6 \times 10^{9}\right.$ and $4 \cdot 1 \times 10^{9}$ respectively) from Penicillium chrysogenum and Cephalosporium acremonium relate to preparations of the latter containing the same amount of DNA as I $\mathrm{g}$ of the corresponding damp-dry mycelium. The mycelium used was harvested $48 \mathrm{~h}$ after inoculation.

$\begin{array}{lcc}\text { Preparation } & \overbrace{\begin{array}{c}\text { Penicillium } \\ \text { chrysogenum }\end{array}}^{\text {Total intracellular amino acids }} \begin{array}{c}\text { Cephalosporium } \\ (\mu \mathrm{M}) \text { in }\end{array} \\ \text { Fresh mycelium } & \mathrm{I} 4 \cdot 6 & 24 \cdot 4 \\ \text { Starved mycelium } & 14 \cdot 7 & \mathrm{I} \cdot 4 \cdot \mathrm{I} \\ \text { Control mycelium } & \mathrm{II} \cdot \mathrm{I} & 24 \cdot 4 \\ \text { Protoplasts } & 2 \mathrm{I} \cdot 2 & \mathrm{I} \cdot 5 \cdot 5\end{array}$

One or occasionally two nuclei, bounded by a nuclear membrane, could be seen in protoplasts from both organisms, although some sections appeared to lack a nucleus (Fig. 4). The nucleoplasm could be distinguished from the cytoplasm, and the darkly staining region which could be seen in most nuclei (Fig. 5) may represent the nucleolar region.

The protoplasts from Cephalosporium acremonium contained one or more vacuoles and smaller vesicles (Fig. 4), whereas those from Penicillium chrysogenum usually contained a large vacuole occupying a considerable proportion of the protoplast (Fig. 6). The vacuoles sometimes contained tubules which formed a network throughout the lumen. Other cytoplasmic inclusions were electron-dense bodies which may have contained lipid. Endoplasmic reticulum could be seen in some sections.

\section{Metabolic activity}

Some of the metabolic activities of the protoplasts were compared with those of control mycelium, treated as for the production of protoplasts except that lytic enzyme was omitted from the medium, and with those of fresh mycelium and starved mycelium in water.

Preliminary experiments showed that the endogenous rate of respiration of a suspension $(2 \mathrm{ml})$ of protoplasts from Cephalosporium acremonium $(8.0 \mu \mathrm{g} \mathrm{DNA} / \mathrm{ml})$ in $0.8 \mathrm{M}-\mathrm{NaCl}$ containing $0.02 \mathrm{M}^{-\mathrm{MgSO}_{4}}$ was $4.9 \mu \mathrm{O}_{2} / \mathrm{min}$. That of a corresponding suspension of control mycelium $(10.2 \mu \mathrm{g} \mathrm{DNA} / \mathrm{ml}$ ) was $5.9 \mu \mathrm{l} \mathrm{O} / \mathrm{min}$. The rate of respiration of a suspension of protoplasts from Penicillium chrysogenum $(7 \cdot 6 \mu \mathrm{g} \mathrm{DNA} / \mathrm{ml})$ was $3.0 \mu 1 \mathrm{O}_{2} / \mathrm{min}$.

Subsequent experiments were carried out to compare the amino acid pools and the activities of some of the amino acid transport systems of protoplasts and mycelium. The transport of valine and $\alpha$-aminoadipic acid was studied, since these amino acids are precursors of penicillin $\mathrm{N}$, isopenicillin $\mathrm{N}$ and cephalosporin $\mathrm{C}$.

Intracellular amino acids. The sizes of the intracellular amino acid pools of protoplasts of Penicillium chrysogenum and Cephalosporium acremonium did not differ greatly from each other or from those of the pools of corresponding fresh mycelia (Table I). The pools were maintained at a high level in starved mycelium and control mycelium.

All the common amino acids appeared to be present in the pools of protoplasts and mycelia of both organisms, together with glutathione, the ' $\mathrm{ACV}$ ' peptides containing $\alpha$-aminoadipic acid and cysteine (Loder \& Abraham, I97I), and other unidentified ninhydrin-positive substances. Free $\alpha$-aminoadipic acid was also detected after paper electrophoresis and chromatography, although its amount could not be determined by the method 
Table 2. Composition of amino acid pools of protoplasts and mycelium

The mycelium was harvested $48 \mathrm{~h}$ after inoculation. Columns I, 2 and 3 refer to fresh, starved and control mycelium respectively.

\begin{tabular}{|c|c|c|c|c|c|c|c|c|}
\hline \multirow[b]{4}{*}{ Amino acid } & \multicolumn{8}{|c|}{ Amount (moles/100 moles) in } \\
\hline & \multicolumn{4}{|c|}{ Penicillium chrysogenum } & \multicolumn{4}{|c|}{ Cephalosporum acremonium } \\
\hline & \multirow[b]{2}{*}{ Protoplasts } & \multicolumn{3}{|c|}{ Mycelium } & \multirow[b]{2}{*}{ Protoplasts } & \multicolumn{3}{|c|}{ Mycelium } \\
\hline & & I & 2 & 3 & & I & 2 & 3 \\
\hline Aspartic acid & 5 & 7 & 5 & 6 & 4 & 8 & 3 & $<\mathrm{I}$ \\
\hline Serine* & 12 & 17 & $2 \mathrm{I}$ & 24 & 21 & II & 15 & 25 \\
\hline Glutamic acid & 15 & I I & 29 & 17 & 13 & 17 & 34 & I 3 \\
\hline Proline & 7 & 3 & 3 & 4 & 28 & 33 & 16 & 23 \\
\hline Glycine & 4 & 4 & 4 & 4 & 6 & 2 & 5 & 5 \\
\hline Alanine & 21 & 26 & 16 & 13 & 9 & 12 & 10 & II \\
\hline Valine & 7 & 3 & 4 & 6 & 4 & 5 & 3 & 3 \\
\hline Methionine & 2 & $<\mathrm{I}$ & $<\mathrm{I}$ & 3 & - & 4 & 3 & 5 \\
\hline Isoleucine & 4 & 2 & 2 & 3 & 2 & 2 & I & 2 \\
\hline Cystine & 1 & 2 & - & - & 2 & $\longrightarrow$ & 一 & $<$ I \\
\hline Lysine & 6 & I & I & 3 & 3 & 2 & 2 & 2 \\
\hline
\end{tabular}

of amino acid analysis used. The relative values for some of the amino acids (in moles/ Ioo moles) are shown in Table 2 . With both organisms glutamic acid, serine and/or substances not resolved from serine (glutamine and asparagine) were major components of the pools. Proline was also a major component in Cephalosporium acremonium and alanine in Penicillium chrysogenum. Histidine and arginine were present in only relatively small amounts.

Uptake of valine. The uptake of valine by protoplasts and mycelium of Cephalosporium acremonium and Penicillium chrysogenum, as reflected by the disappearance of ${ }^{14} \mathrm{C}$ on addition of DL- $\left[\mathrm{I}^{14} \mathrm{C}\right]$ valine to give a low concentration $(0.02 \mu \mathrm{mol} / \mathrm{ml})$ in the suspension fluids, is shown in Fig. 7.

With mycelia of both organisms the uptake of ${ }^{14} \mathrm{C}$ was very rapid until about $50 \%$ of that added initially had disappeared. The subsequent much slower rate of uptake could be attributed, at least in part, to the slow rate of transport of D-valine relative to that of the L-isomer (Warren et al. 1967). With both fungi the rate of uptake by control mycelium in 0.8 to $0.9 \mathrm{M}-\mathrm{NaCl}$ was significantly less than that by fresh mycelium in water, but was similar to that by fresh mycelium in the salt solution. Following the phase of rapid uptake by Cephalosporium acremonium there was a transient small rise in extracellular radioactivity. Some of this rise may have been caused by the excretion of radioactive penicillin $\mathrm{N}$ and cephalosporin C.

$\left[{ }^{14} \mathrm{C}\right]$ Valine was taken up by protoplasts of both organisms, but at a slower rate than by control mycelium. The uptake during the first $90 \mathrm{~min}$, which was accompanied by the appearance of ${ }^{14} \mathrm{C}$ in the intracellular pool (mainly in $\left[{ }^{14} \mathrm{C}\right]$ valine), was almost entirely that of the L-isomer, as is shown for protoplasts of Cephalosporium acremonium in Fig. 8. Direct comparison of the rates of uptake by protoplasts and mycelia, shown in Fig. 7, is complicated by unavoidable differences in the amounts of the preparations used. But Table 3 shows the initial rates by protoplasts which have been calculated for preparations with a DNA content equal to that of the corresponding mycelium. The rates with starved mycelia 

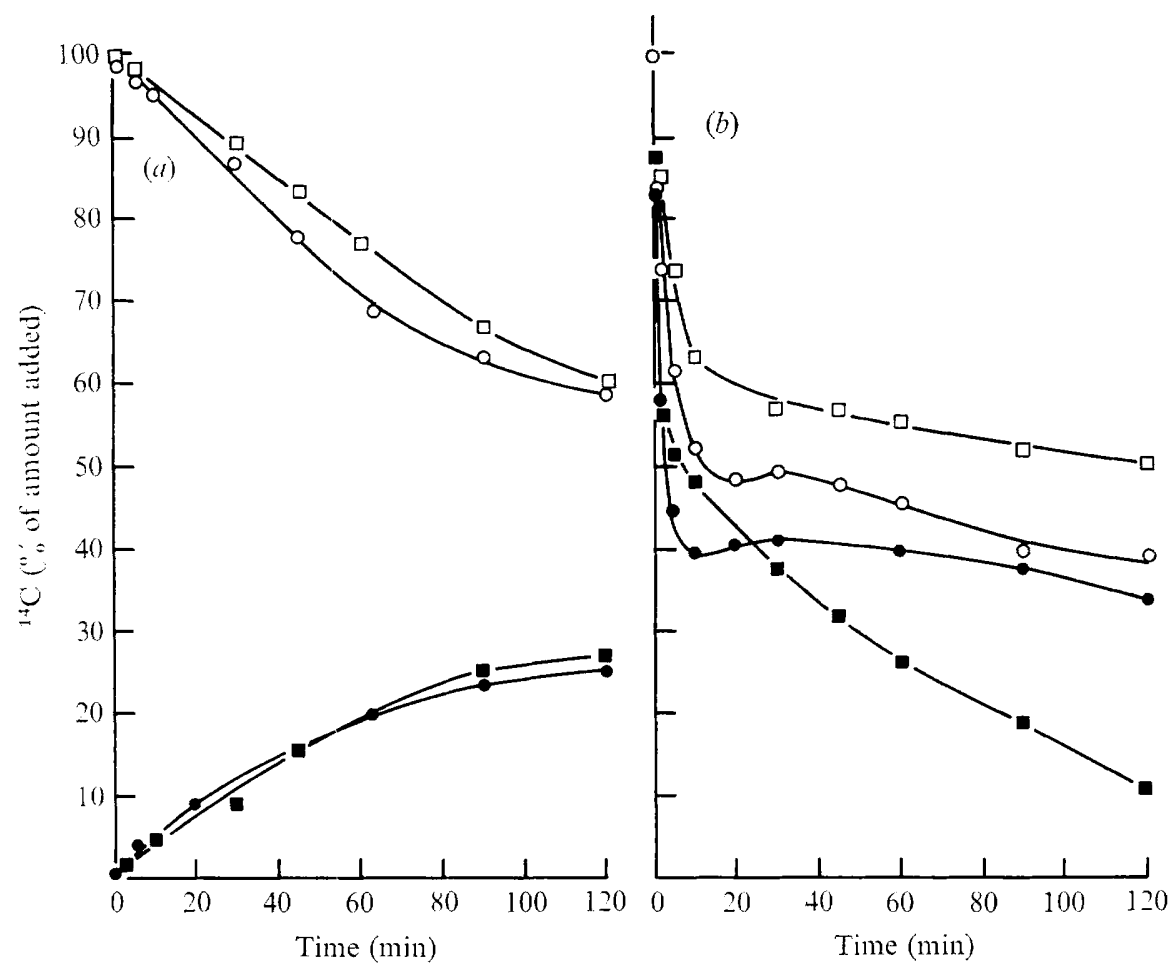

Fig. 7. Uptake of DL- $\left[{ }^{14} \mathrm{C}\right]$ valine $(0.02 \mu \mathrm{mole} / \mathrm{ml})$ by suspensions of protoplasts $(a)$ and mycelium $(b)$. (a) - $\mathrm{O}$-, Extracellular fluid of protoplasts of Cephalosporium acremonium $(20 \mu \mathrm{g} \mathrm{DNA} / \mathrm{ml})$; $\longrightarrow$ - intracellular pool. - $\square$, Extracellular fluid of protoplasts of Penicillium chrysogenum $(7.8 \mu \mathrm{g} \mathrm{DNA} / \mathrm{ml}) ;---$, intracellular pool. (b) - $-\mathrm{O}$-, Control mycelium of $C$. acremonium (3I $\mu \mathrm{g} \mathrm{DNA} / \mathrm{ml}) ;-\longrightarrow$, fresh mycelium. - $\square$, Control mycelium of $P$. chrysogenum (80 $\mu \mathrm{g}$ DNA/ml); - - -, fresh mycelium.

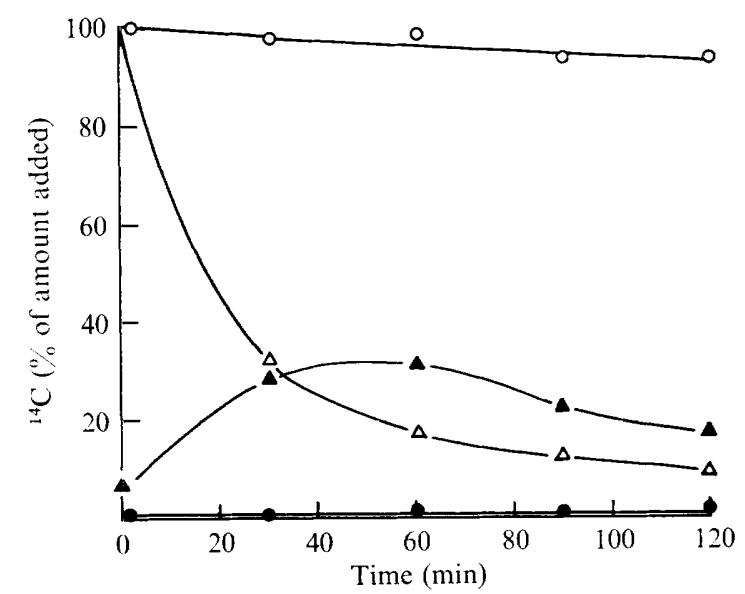

Fig. 8. Uptake of $\mathrm{L}_{-}\left[\mathrm{U}_{-}{ }^{14} \mathrm{C}\right]$ valine $(0.06 \mu \mathrm{mol} / \mathrm{ml})$ and $\mathrm{D}_{-}\left[\mathrm{U}_{-}{ }^{14} \mathrm{C}\right]$ valine $(0 \cdot 02 \mu \mathrm{mol} / \mathrm{ml})$ by protoplasts of Cephalosporium acremonium $(3.9 \mu \mathrm{g} \mathrm{DNA} / \mathrm{ml})$. L- $\left.{ }^{14} \mathrm{C}\right] \mathrm{valine}:-\triangle-$, extracellular fluid; -A-, intracellular pool. D- $\left[{ }^{14} \mathrm{C}\right]$ valine: $-\mathrm{O}-$, extracellular fluid; $-\longrightarrow$, intracellular pool. The protoplasts were in $0.8 \mathrm{M}-\mathrm{NaCl}$ containing $\mathrm{I} \%$ glucose and $0.02 \mathrm{M}-\mathrm{MgSO}_{4}$. 
Table 3. Initial rates of uptake of ${ }^{14} \mathrm{C}$ from $\mathrm{DL}-\left[{ }^{14} \mathrm{C}\right]$ valine by mycelium and protoplasts

The abbreviations (F), (S) and (C) refer to fresh, starved and control mycelium respectively (for details see text). Weights of mycelium refer to damp-dry mycelium after filtration. Initial concentration of DL-[I- $\left.{ }^{14} \mathrm{C}\right]$ valine was $0.02 \mu \mathrm{mol} / \mathrm{ml}$.

\begin{tabular}{|c|c|c|c|c|c|}
\hline Organism & Preparation & $\begin{array}{l}\text { Suspension } \\
\text { fluid }\end{array}$ & $\begin{array}{c}\text { Weight } \\
(\mathrm{g} / 8 \mathrm{ml})\end{array}$ & $\underset{(\mu \mathrm{g} / \mathrm{ml})}{\mathrm{DNA}}$ & $\begin{array}{c}\text { (nmol } \\
\text { L-valine } \\
\mathrm{ml} / \mathrm{min} \text { ) }\end{array}$ \\
\hline Cephalosporium acremonium & $\begin{array}{l}\text { Mycelium (F) } \\
\text { Mycelium (S) } \\
\text { Mycelium (C) } \\
\text { Protoplasts }\end{array}$ & $\begin{array}{l}\text { Water } \\
\text { Water } \\
0.8 \mathrm{M}-\mathrm{NaCl} \\
0.8 \mathrm{M}-\mathrm{NaCl}\end{array}$ & $\begin{array}{l}\text { I.O } \\
\text { I.O } \\
\text { I. } \\
-\end{array}$ & $\begin{array}{l}- \\
3 I \cdot 0 \\
3 r \cdot 0\end{array}$ & $\begin{array}{l}3 \cdot 62 \\
4 \cdot 39 \\
2 \cdot 14 \\
0 \cdot 47\end{array}$ \\
\hline Penicillium chrysogenum & $\begin{array}{l}\text { Mycelium (F) } \\
\text { Mycelium (S) } \\
\text { Mycelium (C) } \\
\text { Protoplasts }\end{array}$ & $\begin{array}{l}\text { Water } \\
\text { Water } \\
0.9 \mathrm{M}-\mathrm{NaCl} \\
0.9 \mathrm{M}-\mathrm{NaCl}\end{array}$ & $\begin{array}{l}1 \cdot 0 \\
1 \cdot 0 \\
1 \cdot 0 \\
-\end{array}$ & $\begin{array}{l}- \\
80 \cdot 0 \\
80 \cdot 0\end{array}$ & $\begin{array}{l}3 \cdot 47 \\
4 \cdot 27 \\
1 \cdot 23 \\
0 \cdot 81\end{array}$ \\
\hline
\end{tabular}

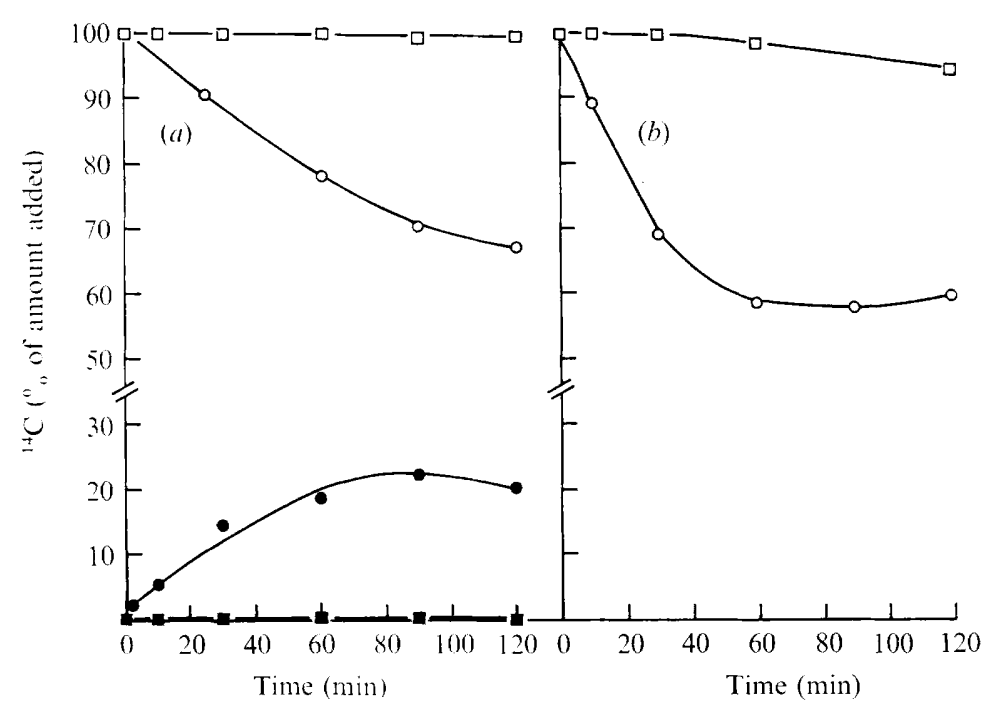

Fig. 9. Uptake of ${ }^{14} \mathrm{C}$ on the addition of DL- $\alpha$-amino[I- $\left.{ }^{14} \mathrm{C}\right]$ adipic acid (initial concentrations 0.025 and $0.043 \mu \mathrm{mol} / \mathrm{ml}$ respectively) to Cephalosporium acremonium and Penicillium chrysogenum protoplast $(a)$ and mycelial $(b)$ suspensions. $(a)-\mathrm{O}-$, Extracellular fluid of protoplasts of C. acremonium $(5 . \mathrm{I} \mu \mathrm{g} \mathrm{DNA} / \mathrm{ml})$ in stabilizer containing $\mathrm{I} \%$ glucose and $0.02 \mathrm{M}-\mathrm{MgSO}_{4}$;

intracellular pool. - $\square-$, Extracellular fluid of protoplasts of $P$. chrysogenum $(4 \circ \mu \mathrm{g} \mathrm{DNA} / \mathrm{ml})$; - - intracellular pool. (b) - $\mathrm{-}$-, Control mycelium of C. acremonium (2I $\mu \mathrm{g} \mathrm{DNA} / \mathrm{ml})$; - $\square$ - control mycelium of $P$. chrysogenum $(64 \mu \mathrm{g} \mathrm{DNA} / \mathrm{ml})$.

were greater than those with fresh mycelia, but the rates with protoplasts were less than those with control mycelia.

Protoplasts of Cephalosporium acremonium prepared in sodium chloride solution as a stabilizer, but resuspended in $0.8 \mathrm{M}-$-mannitol, did not take up ${ }^{14} \mathrm{C}$ on addition of DL-[I- $\left.{ }^{14} \mathrm{C}\right]-$ valine. The control mycelium in mannitol also failed to take up valine.

Uptake of $\alpha$-aminoadipic acid. The uptake of ${ }^{14} \mathrm{C}$ on addition of $\mathrm{DL}-\alpha$-amino[ $\left.\mathrm{I}-{ }^{14} \mathrm{C}\right] \mathrm{adipic}$ acid to suspensions of protoplasts and mycelium is shown in Fig. 9, and is assumed to be mainly the result of transport of the L-isomer (Warren et al. 1967). During the first $30 \mathrm{~min}$ the rate of uptake by protoplasts of Cephalosporium acremonium was similar to that calcu- 


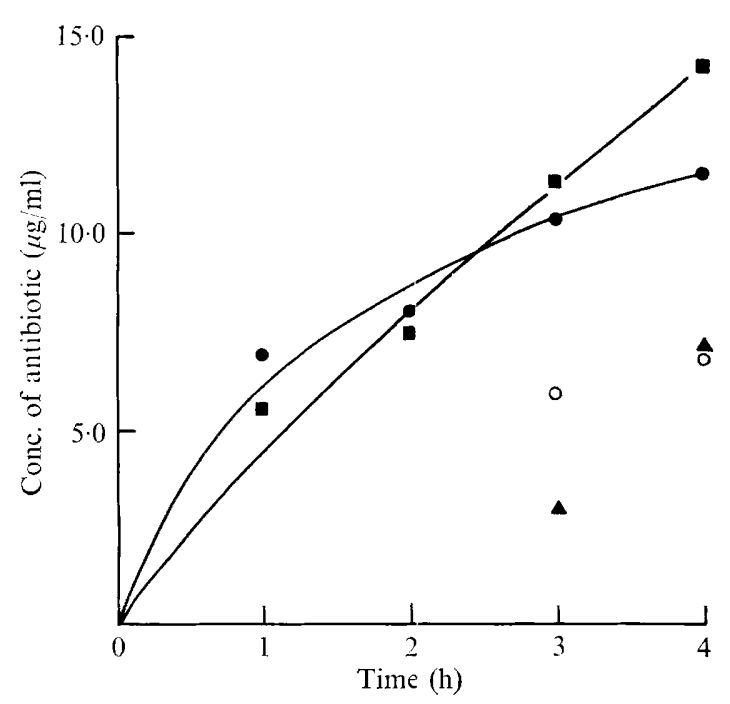

Fig. 10

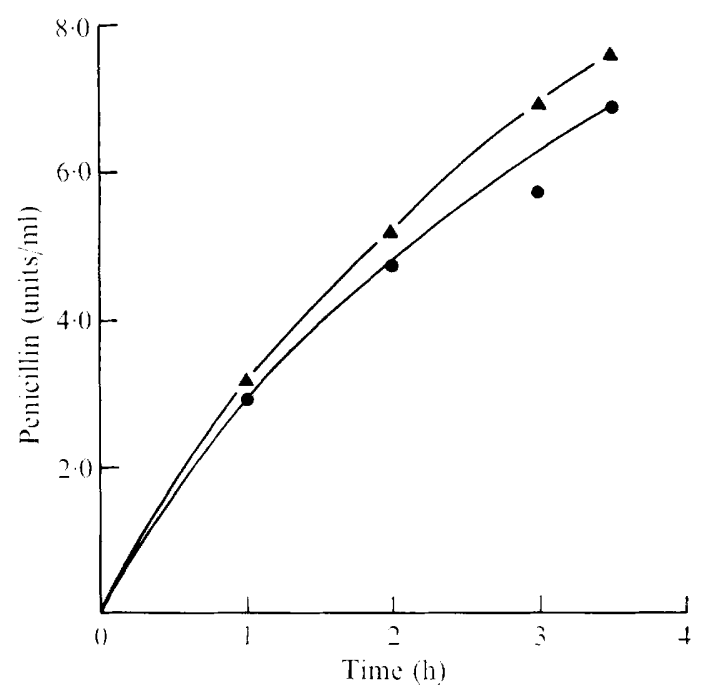

Fig. I I

Fig. Io. Production of penicillin $\mathrm{N}$ and cephalosporin $\mathrm{C}$ by suspensions of protoplasts (I $2 \cdot \mathrm{I} \mu \mathrm{g}$ $\mathrm{DNA} / \mathrm{ml})$ and mycelium $(26.0 \mu \mathrm{g} \mathrm{DNA} / \mathrm{ml})$ of Cephalosporium acremonium. Both suspensions were in $0.8 \mathrm{M}-\mathrm{NaCl}$ containing $\mathrm{I} \%$ glucose and $0.02 \mathrm{M}-\mathrm{MgSO}_{4}$. Penicillin $\mathrm{N}$ : - - , protoplasts; - -, mycelium. Cephalosporin $\mathrm{C}:-\mathrm{O}-$, protoplasts; $-\mathbf{A}-$, mycelium.

Fig. I I. Production of penicillin by suspensions in $0.9 \mathrm{M}-\mathrm{NaCl}$ containing $0.05 \%$ sodium phenylacetate of protoplasts and control mycelium $(80 \cdot 7 \mu \mathrm{g} \mathrm{DNA} / \mathrm{ml})$ of Penicillium chrysogenum. - - Protoplasts; - $\mathbf{A -}$-, mycelium.

lated for suspensions of control or fresh mycelium of this organism containing the same amount of DNA. During the same time, neither protoplasts nor control mycelium of Penicillium chrysogenum took up this amino acid at a significant rate in sodium chloride alone or containing $0.02 \mathrm{M}-\mathrm{MgSO}_{4}$. In contrast, fresh mycelium removed $40 \%$ of the ${ }^{14} \mathrm{C}$ from the extracellular fluid during $\mathrm{I} h$.

The $\delta$-ethyl ester of $\mathrm{DL}-\alpha$-aminoadipic acid was also not taken up by protoplasts of Penicillium chrysogenum, but the initial uptake of this compound by fresh mycelium of $P$. chrysogenum was much more rapid than the uptake of $\alpha$-aminoadipic and resembled that of the L-isomer of DL-valine. On the other hand the rate of uptake of the $\delta$-ester by fresh mycelium of Cephalosporium acremonium was similar to that of $\alpha$-aminoadipic acid itself.

Antibiotic production. The production of penicillin $\mathrm{N}$ and cephalosporin $\mathrm{C}$ by suspensions of protoplasts and control mycelium of Cephalosporium acremonium is shown in Fig. Io. The mycelium used was harvested $48 \mathrm{~h}$ after inoculation. When allowance was made for the difference in the DNA content of the two preparations, it appeared that the protoplasts produced antibiotics somewhat more rapidly than control mycelium, although in both cases cephalosporin $\mathrm{C}$ was only detectable after $3 \mathrm{~h}$ and no reliable measurement of the rate of its production was possible. Addition of a variety of amino acids, including $\alpha$-aminoadipic acid, cysteine and valine, failed to stimulate antibiotic production by either suspension. The initial rate of production by control mycelium was about $60 \%$ of that by fresh mycelium in water and about $85 \%$ of that by starved mycelium in water.

Antibiotic production appeared to be unaffected when protoplasts prepared in a sodium chloride stabilizer were resuspended in $0.9 \mathrm{M}-\mathrm{NH}_{4} \mathrm{Cl}$. However, protoplasts prepared in 
ammonium chloride, which were relatively deficient in DNA, failed to produce detectable levels of penicillin $\mathrm{N}$ or cephalosporin $\mathrm{C}$.

The production of penicillin by suspensions of protoplasts and control mycelium of Penicillium chrysogenum is shown in Fig. II. The experimental values obtained with the protoplast suspension used (containing $20 \mu \mathrm{g} \mathrm{DNA} / \mathrm{ml}$ ) have been adjusted to correspond to those for a suspension containing the same amount of DNA $(80.7 \mu \mathrm{g} \mathrm{DNA} / \mathrm{ml})$ as the mycelial suspension. On this basis antibiotic production by the protoplasts did not differ significantly from that by the control mycelium. However, the rate of production by the latter was only about $25 \%$ of that by fresh mycelium or starved mycelium.

\section{DISCUSSION}

The behaviour of Penicillium chrysogenum $\mathrm{C} 2 \mathrm{I}$ and Cephalosporium acremonium C9I to lytic enzyme preparations shows that the multilayered hyphal walls of both organisms change with the age of the cultures and that of the wall of the Penicillium differs significantly from that of the Cephalosporium. The main constituents of the hyphal wall of $P$. chrysogenum have been reported to be a glucan and chitin (Troy \& Koffler, I969), and the finding that this organism, unlike C. acremonium, is more susceptible to a crude enzyme preparation from Helix pomatia than it is to one from Cytophaga may be associated with the high chitinase activity of the former.

The finding that protoplast formation from Cephalosporium acremonium required pretreatment of the mycelium with a thiol parallels similar findings with yeasts, which led to the suggestion that the thiol reduced disulphide bonds linking protein to mannan (Nickerson \& Falcone, 1956). Dithiothreitol has also been found to be more effective with yeasts than 2-mercaptoethanol (Sommer \& Lewis, 197I). Electron micrographs showed that there were no gross changes in the hyphal wall of $C$. acremonium after dithiothreitol treatment, although the cytoplasm may have withdrawn from some parts of the inner layer of the wall. But the reason why no pretreatment was required with Penicillium chrysogenum C2 I remains to be ascertained.

The appearance of the protoplast mitochondria in electron micrographs, together with the ability of the protoplasts to respire, to maintain an intracellular amino-acid pool, to transport amino acids, and to produce $\beta$-lactam antibiotics, indicated that the major energyyielding systems remained largely intact during protoplast formation. Nevertheless, the gradual swelling of the protoplasts with time in sodium chloride solution suggested that one or more of these systems was slowly becoming less efficient.

The uptake of $\mathrm{L}-\left[\mathrm{U}-{ }^{14} \mathrm{C}\right]$ valine by protoplasts of Cephalosporium acremonium during $\mathrm{I} \mathrm{h}$ resulted in the disappearance of about $75 \%$ of the added labelled valine from the extracellular fluid and the appearance of about $30 \%$ in the intracellular pool. Since valine was not excreted by the protoplasts, its extracellular concentration fell from $0.06 \mu \mathrm{mol} / \mathrm{ml}$ to about $0.015 \mu \mathrm{mol} / \mathrm{ml}$. The total intracellular volume of the protoplasts (calculated from their number and average diameter) was less than $\mathrm{i} \%$ of the volume of the extracellular fluid. From the size and composition of the intracellular pool it can be calculated that the concentration of unlabelled valine in the pool would be $>2 \mu \mathrm{mol} / \mathrm{ml}$ if it were diffusible throughout the protoplast volume. If the pool were freely expandable the total intracellular concentration of valine could rise to $>4 \mu \mathrm{mol} / \mathrm{ml}$ with the entry of $\mathrm{L}-\left[\mathrm{U}-{ }^{14} \mathrm{C}\right]$ valine from the extracellular fluid. On these assumptions the valine would enter the protoplast against a steep concentration gradient (between at least 30 and 300 to $\mathrm{I}$ ), presumably by active transport. 
However, comparison of the behaviour of protoplasts with fresh mycelium and of the latter with control mycelium indicates that high concentrations of sodium chloride interfere with amino acid uptake. Comparison of protoplasts with control mycelium also raises the question whether some part of the transport system was lost or damaged during protoplast formation. More detailed studies of rates of transport and their variation as a function of amino acid concentration are required to throw further light on these questions.

With both Cephalosporium acremonium and Penicillium chrysogenum the age of the culture at which maximum yields of protoplasts were obtained did not differ greatly from those at which the rate of antibiotic production per unit weight of mycelium was at its highest level. Both the time required for protoplast formation and the presence of the sodium chloride osmotic stabilizer appeared to contribute to a reduction in the rate of production by protoplasts of about $60 \%$ of that by suspensions in water of fresh mycelium. Other factors, such as the relative efficiency of aeration with protoplast and mycelial suspensions respectively, complicate attempts to compare the activities of the biosynthetic systems in the first type of suspension with those in the second. Nevertheless, the rates of antibiotic production by protoplasts of both $C$. acremonium $\mathrm{C} 9 \mathrm{I}$ and $P$. chrysogenum $\mathrm{C2}$ I appear to be sufficiently close to those with the corresponding intact mycelia for the protoplasts to be potential sources of antibiotic-producing cell-free systems.

We thank Dr D. Kay and Miss Mary Bergin, who kindly prepared the electron micrographs and assisted with their interpretation, and Mrs Sheila Francis for technical assistance. We are indebted to Dr W. F. J. Cuthbertson and Dr J. F. Peberdy for gifts of lytic enzymes, to Dr K. Gull for advice on nuclear staining and to Dr P. Corran for amino acid analyses. We thank the Medical Research Council and the National Research Development Corporation for financial support.

\section{REFERENCES}

Abraham, E. P. \& Newton, G. G. F. (1954). Synthesis of D- $\delta$-amino- $\delta$-carboxyvalerylglycine (a degradation product of cephalosporin N) and of DL- $\delta$-amino- $\delta$-carboxyvaleramide. Biochemical Journal 58, $266-268$.

Bruno, G. A. \& Christian, J. E. (196I). Correction for quenching associated with liquid scintillation counting. Analytical Chemistry 33, 650-65I.

Burton, K. (1968). Determination of DNA concentration with diphenylamine. In Methods in Enzymology, vol. XIIB, pp. 163-166. Edited by L. Grossman and K. Moldave. New York: Academic Press.

Gailey, F. B., Stefaniak, J. J., Olson, B. H. \& Johnson, M. J. (I946). A comparison of penicillin-producing strains of Penicillium notatum-chrysogenum. Journal of Bacteriology 52, 129-140.

García López, M. D., Rodriguez Aguirre, M. J., Uruburu, F. \& Villanueva, J. R. (1967). Characterization of the lytic Streptomyces RA as a new strain of Streptomyces venezulae. Antonie van Leeuwenhoek 33, 315-323.

Gibson, R. K. \& Peberdy, J. F. (1972). Fine structure of protoplasts of Aspergillus nidulans. Journal of General Microbiology 72, 529-538.

IshiHARA, H., SASAKI, T. \& SHIMURA, K. (1968). Biosynthesis of bacitracin. II. Incorporation of ${ }^{14}$ C-labelled amino acids into bacitracin by a cell-free preparation from Bacillus licheniformis. Biochimica et biophysica acta $166,496-504$.

JARvis, F. G. \& Johnson, M. J. (I947). The role of the constituents of synthetic media for penicillin production. Journal of the American Chemical Society 69, 3010-3017.

Kellenberger, E., Ryter, A. \& Sechaud, J. (1958). Electron microscope study of DNA-containing plasms. II. Vegetative and mature phage DNA as compared with normal bacterial nucleoids in different physiological states. Journal of Biophysical and Biochemical Cytology 4, 67 I-678.

Loder, P. B. \& Abraham, E. P. (I97I). Biosynthesis of peptides containing $\alpha$-aminoadipic acid and cysteine in extracts of a Cephalosporium sp. Biochemical Journal r23, 477-482.

Loder, P. B., Abraham, E. P. \& Newton, G. G. F. (I969). Behaviour of $\alpha$-aminoadipylcysteine and glutamylcysteine in the presence of intact and disrupted mycelium of a Cephalosporium sp. Biochemical Journal Ir2, 389-396. 
Lowry, O. H., Rosebrough, N. J., FARr, A. L. \& Randall, R. J. (195I). Protein measurement with the Folin phenol reagent. Journal of Biological Chemistry 193, 265-275.

Marini, F., ARnow, P. \& LAMPen, J. O. (1961). The effects of monovalent cations on the inhibition of yeast metabolism by nystatin. Journal of General Microbiology 24, $5 \mathrm{I}-62$.

MCIlvaine, T. C. (I92I). A buffer solution for colorimetric comparison. Journal of Biological Chemistry 49, $183-186$.

Nickerson. W. J. \& Falcone, G. (1956). Enzymatic reduction of disulphide bonds in cell wall protein of baker's yeast. Science, New York 124, 318-319.

ReYNolds, E. S. (1963). The use of lead citrate at high $\mathrm{pH}$ as an electron-opaque stain in electron microscopy. Journal of Cell Biology 17, 208-212.

Shimura, K., Sasaki, T. \& Sugawara, K. (1964). Biosynthesis of bacitracin. I. Formation of bacitracin by a subcellular fraction of Bacillus licheniformis. Biochimica et biophysica acta 86, 46-55.

Smith, B., Warren, S. C., Newton, G. G. F. \& Abraham, E. P. (I967). Biosynthesis of penicillin N and cephalosporin C. Antibiotic production and other features of the metabolism of a Cephalosporium sp. Biochemical Journal 103, 877-890.

SOMmer, A. \& Lewis, M. J. (197I). Effect of dithiothreitol on yeast: sphaeroplast formation and invertase release. Journal of General Microbiology 68, 327-335.

Spackman, D. H., Stein, W. H. \& Moore, S. ( I958). Automatic recording apparatus for use in the chromatography of amino acids. Analytical Chemistry 30, I I90-I 206.

TARDREw, P. L. \& Johnson, M. J. (1958). Sulphate utilization by penicillin-producing mutants of Penicillium chrysogenum. Journal of Bacteriology $76,400$.

Troy, F. A. \& Koffler, H. (1969). The chemistry and molecular architecture of the cell wall of Penicillium chrysogenum. Journal of Biological Chemistry 224, 5563-5576.

Warren, S. C., Newton, G. G. F. \& Abraham, E. P. (1967). The role of valine in the biosynthesis of penicillin $\mathrm{N}$ and cephalosporin $\mathrm{C}$ by a Cephalosporium sp. Biochemical Journal 1o3, 902 . 